\title{
PENGARUH DIVIDEND YIELD, RETENTION RATIO, EPS, DAN ROE TERHADAP HARGA SAHAM
}

\author{
Rista Puput Aryanti \\ Universitas Widya Mataram \\ Email : ristaryanti14@gmail.com
}

\begin{abstract}
This research intends to analyze the influence of Dividend Yield, Retention Ratio, Earnings per Share (or EPS), and Return on Equity (or ROE) on the Stock Price. It examines arrange of data set form Banks Company and in Indonesia Stock Exchange between 2012-2014. The researcher utilizes purposive sampling method with 25 Banks Company. The analysis technique used here is multiple regression with the least square difference and hypothesis test using $t$-statistic to examine partial regression coefficient and f-statistic to examine the mean of mutual effect with level of significant $5 \%$.
\end{abstract}

Keywords: Dividend Yield, Retention Ratio, EPS, ROE, and Stock Price

\section{PENDAHULUAN}

Perkembangan dunia usaha yang semakin kompetitif membutuhkan keikutsertaan para pelaku usaha untuk lebih aktif dalam menarik investor domestik dan mancanegara. Pasar modal merupakan tempat bertemunya antara pihak yang memerlukan modal dengan pemilik modal baik perorangan maupun kelompok. Pasar modal mempunyai peranan penting untuk dapat memenuhi kebutuhan modal bagi dunia usaha agar tetap eksis dalam perekonomian global. Pasar modal merupakan pertemuan antara pihak yang memiliki kelebihan dana dengan pihak yang membutuhkan dana dengan cara memperjualbelikan sekuritas (Tandelilin, 2001:13). Saham sebagai surat berharga yang paling sering diperdagangkan di pasar modal harganya selalu mengalami fluktuasi dari waktu ke waktu. Fluktuasi harga saham selalu menjadi daya tarik dan pusat perhatian bagi investor di pasar modal.

Pertumbuhan perusahaan dan dividen adalah kedua hal yang diinginkan perusahaan tetapi sekaligus merupakan suatu tujuan yang berlawanan. Untuk mencapai tujuan tadi perusahaan menetapkan kebijakan dividen yaitu kebijakan yang dibuat oleh perusahaan untuk menetapkan proporsi pendapatan yang dibagikan sebagai dividen yang dibayar, berarti semakin sedikit laba yang dapat ditahan dan sebagai akibatnya ialah menghambat tingkat pertumbuhan laba dan harga sahamnya. Sebaliknya, jika perusahaan ingin menahan sebagian besar labanya tetap di dalam perusahaan berarti bagian dari laba yang tersedia untuk pembayaran dividen adalah semakin kecil. Akibatnya, dividen yang diterima pemegang saham atau investor bisa dan tidak sebanding dengan resiko yang mereka tanggung. Kebijakan dividen merupakan kebijakan yang penting terkait dengan nilai perusahaan karena dari kebijakan tersebut tercermin bagaimana kinerja saham perusahaan serta bagaimana usaha perusahaan dalam mensejahterakan pemilik perusahaan dengan pembagian keuntungan perusahaan dari hasil laba perusahaan.

Pentingnya informasi kebijakan dividen bagi investor dan pemegang saham perusahaan juga telah dibuktikan pada penelitian sebelumnya, Laitupa (2007) dalam penelitiannya mengungkapkan bahwa terdapat dua tujuan utama investor dalam berinvestasi di pasar modal yaitu tujuan investasi jangka panjang dan tujuan investasi jangka pendek yang keduanya terkait dengan tujuan untuk mendapatkan keuntungan dari kepemilikan saham perusahaan. 
Penelitian ini akan membahas bagaimana pengaruh Dividend Yield, Retention Ratio, EPS, ROE terhadap Harga Saham pada Perusahan Perbankan periode tahun 2012 - 2014.

\section{LANDASAN TEORI \\ Landasan Teori \\ Irrelevance Theory}

Irrelevance theory adalah suatu teori yang menyatakan bahwa kebijakan dividen tidak mempunyai pengaruh baik terhadap nilai perusahaan maupun terhadap biaya modalnya. Menurut teori ini, kebijakan dividen tidak mempengaruhi harga saham ataupun cost of capital perusahaan. Oleh karena itu, kebijakan dividen menjadi tidak relevan (irrelevant). Teori ini dikembangkan oleh Miller dan Modigliani (1961), yang menyatakan bahwa nilai perusahaan hanya ditentukan oleh expected earnings dan risiko perusahaan. Nilai perusahaan hanya tergantung pada laba yang diekspektasikan dari aktiva, bukan dari pemisahan laba menjadi dividen dan laba ditahan. Teori ini menganggap bahwa kebijakan dividen tidak membawa dampak apa-apa bagi nilai perusahaan. Jadi, peningkatan atau penurunan dividen oleh perusahaan tidak akan mempengaruhi nilai perusahaan.

\section{The Bird in the Hand Theory}

Teori ini menyatakan bahwa biaya modal sendiri perusahaan akan naik jika presentase laba yang dibayarkan kepada pemegang saham dalam bentuk uang tunai atau DPR (Dividen Payout Ratio) rendah, karena investor lebih suka menerima dividen dari pada perolehan modal (Capital Gains). Investor memandang keuntungan dividen (dividend yield) lebih pasti dari pada keuntungan capital gains (capital gains yield). Laba ditahan adalah keuntungan dari dividen (dividend yield) ditambah keuntungan dari capital gains (capital gains yield).

\section{Saham}

Saham dapat didefinisikan sebagai tanda penyertaan atau kepemilikan seseorang atau badan dalam suatu perusahaan atau perseroan terbatas. Saham berwujud selembar kertas yang menerangkan bahwa pemilik kertas tersebut adalah pemilik perusahaan yang menerbitkan surat berharga tersebut. Besarnya kepemilikan ditentukan oleh seberapa besar penyertaan yang ditanamkan di perusahaan tersebut (Darmadji dan Fakhruddin, 2008). Saham merupakan salah satu bentuk surat berharga yang diperdagangkan di bursa. Menurut Robbert Ang (1997), saham adalah surat berharga sebagai bukti penyertaan atau kepemilikan individu maupun organisasi (instansi) dalam suatu perusahaan. Harga saham mengalami perubahan naik atau turun pada waktu tertentu Perubahan tersebut tergantung pada kekuatan permintaan dan penawaran, jika suatu saham mengalami kenaikan permintaan, maka harga saham cenderung naik. Sebaliknya jika terjadi kenaikan penawaran

maka harga saham akan cenderung turun.

\section{Pasar Modal}

Menurut Undang-Undang Pasar Modal No.8 tahun 1995, pasar modal adalah kegiatan yang bersangkutan dengan penawaran umum dan perdagangan efek, perusahaan publik yang berkaitan dengan efek yang diterbitkannya serta lembaga dan profesi yang berkaitan dengan efek. Menurut Robbert Ang (1997), pasar modal merupakan suatu situasi para penjual dan pembeli dapat melakukan negosiasi terhadap pertukaran suatu komoditas atau kelompok komoditas. Pasar modal merupakan indikator kemajuan perekonomian suatu negara serta menunjang perkembangan ekonomi negara yang bersangkutan. Didalam berputarnya roda perkonomian suatu negara, sumber dana bagi pembiayaan- 
pembiayaan beroperasinya suatu perusahaan-perusahaan yang merupakan tulang ekonomi suatu negara sangat terbatas, maka perlu dicarikan adanya solusi pembiayaan yang bersifat jangka panjang. Dengan adanya pasar modal, maka makin banyak perusahaan yang akan go-public. Artinya sebagian saham dari perusahaan-perusahaan tersebut akan ikut dimiliki oleh masyarakat luas, yang berarti secara makro ekonomi merupakan pemerataan pendapatan

\section{Pengembangan Hipotesis}

\section{1) Pengaruh Dividend Yield terhadap Harga Saham}

Dividend Yield adalah suatu rasio yang menghubungkan dividen yang dibayar dengan harga saham biasa. Dividend Yield menyediakan suatu ukuran komponen pengembalian total yang dihasilkan dividen, dengan menambahkan apresiasi harga yang ada. Beberapa investor menggunakan dividend yield sebagai suatu ukuran risiko dan sebagai suatu penyaring investasi, yaitu mereka akan berusaha menginvestasikan dananya dalam saham yang menghasilkan dividend yield yang tinggi. Ini sesuai dengan teori Bird In The Hand yang menyatakan bahwa biaya modal sendiri perusahaan akan naik jika presentase laba yang dibayarkan kepada pemegang saham dalam bentuk uang tunai atau DPR (Dividen Payout Ratio) rendah, karena investor lebih suka menerima dividen dari pada perolehan modal (Capital Gains). Tingkat pengembalian yang didapat oleh investor dalam bentuk dividend yield akan membuat investor bereaksi dan membentuk harga saham baru di pasar atas perusahaan tersebut. Semakin besar dividend yield yang didapat oleh investor, akan semakin kecil tingkat volatilitas harga saham perusahaan tersebut.

\section{H1 : Dividend Yield berpengaruh positif terhadap harga saham.}

\section{2) Pengaruh Retention Ratio terhadap Harga Saham}

Retention Ratio merupakan rasio yang menunjukkan tingkat keuntungan yang tidak dibagikan kepada pemegang saham sebagai dividen. Retention Ratio juga merupakan rasio yang menunjukkan perbandingan antara perubahan laba ditahan dengan laba bersih setelah bunga dan pajak. Jika Retention Ratio menunjukkan angka positif berarti dari laba yang dihasilkan sebagian ditanamkan kembali kedalam perusahaan, laba yang tidak dibagikan ini akan menambah jumlah modal sendiri dan berpengaruh terhadap tingkat pertumbuhan modal sendiri. Pengurangan persentase laba bersih yang dibayarkan untuk deviden akan meningkatkan retention ratio. Hal ini akan menghasilkan ekuitas secara internal dan meningkatkan pertumbuhan sustain atau dipertahankan. Hubungannya dengan pertumbuhan perusahaan, semakin tinggi Retention Ratio maka akan meningkatkan kemampuan perusahaan dalam memperoleh dana internal yang didapat melalui laba ditahan perusahaan sehingga kemampuan perusahaan untuk mendanai aktivitas penjualannya meningkat.

\section{H2 : Retention Ratio berpengaruh negatif terhadap harga saham.}

\section{3) Pengaruh EPS terhadap Harga Saham}

Setiap modal atau dana yang akan diinvestasikan selalu mengaitkan antara risiko dengan hasil yang akan diperoleh. Oleh karena itu, para investor yang akan berinvestasi selalu memperhatikan dan menganalisis dengan cermat dan teliti kondisi perusahaan dimana investor tersebut akan menanamkan modalnya. Kinerja perusahaan yang baik atau buruk pasti akan direspon para investor di dua pasar modal dan hal tersebut akan mempengaruhi keputusan investor untuk berinvestasi. Dalam hal menganalisis sebuah perusahaan, investor dapat menggunakan laporan keuangan untuk menilai kondisi perusahaan. EPS dapat dihitung dengan membagi laba yang tersedia bagi pemegang saham biasa dengan jumlah saham yang beredar selama periode perhitungan dilakukan. Para calon pemegang saham tertarik dengan EPS yang besar, karena hal ini merupakan salah satu indikator keberhasilan suatu perusahaan. 


\title{
H3 : EPS berpengaruh positif terhadap harga saham.
}

\section{4) Pengaruh ROE terhadap Harga Saham}

ROE merupakan kemampuan perusahaan dalam menghasilkan keuntungan dengan menggunakan modal sendiri. ROE disebut juga tingkat pengembalian atas ekuitas pemilik perusahaan, ekuitas pemilik adalah jumlah aktiva bersih perusahaan. ROE mengukur kemampuan perusahaan memperoleh laba yang tersedia bagi pemegang saham perusahaan. Rasio ini sangat diperhatikan oleh para pemegang saham karena para pemegang saham lebih memilih ROE yang tinggi. Dengan kata lain semakin tinggi ROE menunjukkan penggunaan modal sendiri yang dimiliki perusahaan semakin tinggi dapat menghasilkan laba bersih, maka semakin banyak juga investor yang akan menginvestasikan dananya (Wardjono, 2010).

\section{H4 : ROE berpengaruh positif terhadap harga saham.}

Bagi investor jangka panjang, informasi kebijakan dividen berguna untuk mengetahui sejarah pembayaran dividen tunai perusahaan emiten. Investor pengharap imbalan dividen umumnya menginginkan pembagian dividen yang relatif stabil, karena dengan stabilitas pembayaran dividen dapat meningkatkan kepercayaan investor terhadap perusahaan sehingga mengurangi ketidakpastian investor dalam menanamkan dananya kedalam perusahaan. Bagi investor jangka pendek, pengharap imbalan capital gain, informasi kebijakan dividen berguna untuk meramalkan harga saham di masa mendatang. Dividen ini penting artinya bagi investor, karena hal itu menunjukkan bahwa manajemen perusahaan telah bekerja keras untuk mencapai pertumbuhan laba semaksimal mungkin untuk kepentingan pemegang saham.

Hubungan logis antar variabel-variabel dalam penelitian ini akan dijelaskan dan divisualisasikan dalam kerangka pemikiran berikut ini:

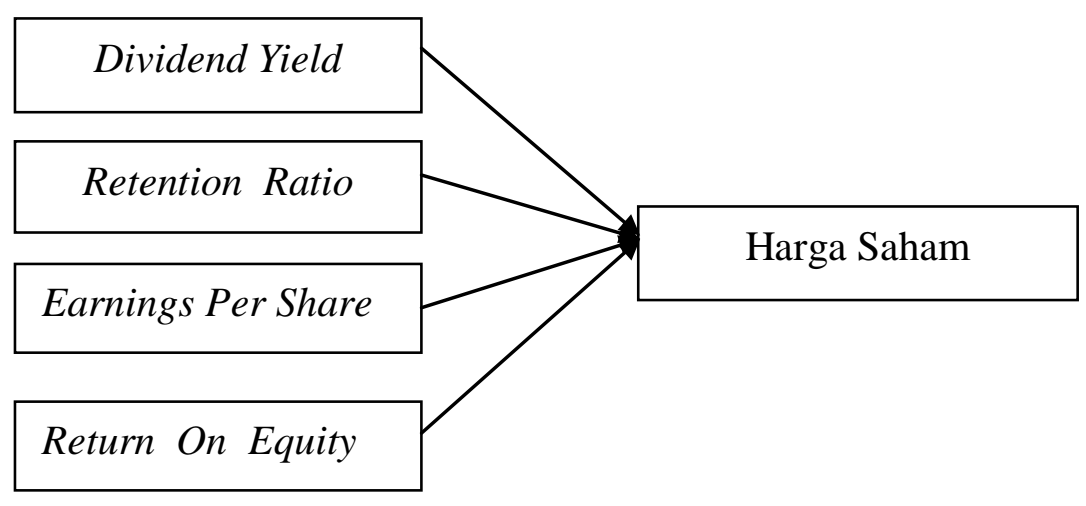

\author{
Gambar 1 \\ Model Penelitian
}

\section{METODE PENELITIAN}

\section{Jenis Penelitian}

Jenis data yang digunakan dalam penelitian ini adalah data sekunder. Data sekunder merupakan data yang diperoleh secara tidak langsung melalui media perantara, baik yang dipublikasikan dan tidak dipublikasikan. Data sekunder dalam penelitian ini berupa laporan keuangan masing-masing perusahaan publik periode tahun 2012-2014, serta data perusahan yang diperoleh dari www.idx.co.id dan Indonesian Capital Market Directory (ICMD). 


\section{Populasi dan Sampel}

Populasi dalam penelitian ini mencakup semua perusahaan perbankan dan perusahaan Lembaga Keuangan Bukan Bank (LKBB) yang terdaftar di Bursa Efek Indonesia. Adapun periode yang digunakan dalam penelitian ini adalah tahun 2012-2014. Pengambilan sampel menggunakan metode purposive sampling, yaitu sampel dipilih dengan menggunakan pertimbangan tertentu yang disesuaikan dengan tujuan penelitian atau masalah penelitian yang dikembangkan.

\section{Metode Pengumpulan Data}

Metode pengumpulan data yang digunakan dalam penelitian ini adalah metode dokumenter, yaitu teknik pengambilan data dengan cara mengumpulkan, mencatat dan mengkaji data sekunder yang berupa laporan keuangan perusahaan manufaktur yang dipublikasikan oleh Bursa Efek Indonesia atau akses internet melalui www.bapepam.co.id dan www.jsx.co.id dan dilengkapi dengan informasi tambahan yang diperoleh dari Indonesian Capital Market Directory (ICMD), serta dari berbagai buku pendukung dan sumber-sumber lainnya yang berhubungan dengan harga saham.

\section{HASIL ANALISIS DAN PEMBAHASAN}

\section{Hasil Analisis}

Dalam analisis data, kami melakukan uji pada beberapa tahap mulai dari uji normalitas, uji multikolinearitas, uji heteroskedastisitas, uji autokorelasi, uji parsial, uji menyeluruh serta uji koefisien determinasi. Berikut adalah hasil dari analisis data.

\section{Uji Normalitas}

Tabel 1 Hasil Uji Normalitas

\begin{tabular}{|ll|r|}
\hline & & $\begin{array}{r}\text { Unstandardi } \\
\text { zed Residual }\end{array}$ \\
\hline $\mathrm{N}$ & Mean & 75 \\
Normal & 0,0000000 \\
Parameters(a,b) & Std. Deviation & 0,44233925 \\
Most Extreme & Absolute & 0,091 \\
Differences & Positive & 0,091 \\
\multicolumn{2}{|c|}{ Negative } & $-0,053$ \\
Kolmogorov-Smirnov Z & 0,792 \\
Asymp. Sig. (2-tailed) & 0,557 \\
\hline
\end{tabular}

Berdasarkan Tabel 1 di atas, dapat diketahui bahwa uji kolmogorov-smirnov test memiliki nilai signifikansi sebesar 0,557 lebih besar dari 0,05, maka model regresi yang digunakan mempunyai standar error yang normal, sehingga dapat disimpulkan bahwa model regresi dapat diuji lebih lanjut untuk mengetahui pengaruh masing-masing variabel bebas terhadap variabel terikat. 


\section{Uji Multikolinearitas}

Tabel 2. Hasil Uji Multikolinearitas

\begin{tabular}{|rl|r|r|}
\hline \multirow{2}{*}{ Model } & \multicolumn{2}{|c|}{ Collinearity Statistics } \\
\cline { 3 - 4 } & & \multicolumn{1}{c|}{ Tolerance } & \multicolumn{1}{c|}{ VIF } \\
\hline 1 & (Constant) & & \\
& Dividend.Yield & 0,862 & 1,160 \\
& Retention.Ratio & 0,531 & 1,883 \\
& EPS & 0,338 & 2,960 \\
& ROE & 0,360 & 2,780 \\
\hline
\end{tabular}

Dari Tabel 2 uji multikolinearitas di atas, diketahui bahwa seluruh variabel independen model regresi mempunyai nilai VIF yang kurang dari 10 dan nilai tolerance lebih besar dari 0,10 , sehingga seluruh variabel independen yang digunakan pada model persamaan regresi tidak ada multikolinearitas (tidak ada hubungan yang sangat kuat antara variabel independen).

\section{Uji Autokorelasi Data}

Tabel 3. Hasil Uji Autokorelasi

\begin{tabular}{|l|r|r|r|r|r|}
\hline Model & R & R Square & $\begin{array}{c}\text { Adjusted } \\
\text { R Square }\end{array}$ & $\begin{array}{c}\text { Std. Error of } \\
\text { the Estimate }\end{array}$ & $\begin{array}{c}\text { Durbin- } \\
\text { Watson }\end{array}$ \\
\hline 1 & $0,951^{\mathrm{a}}$ & 0,905 & 0,900 & 0,45480 & 1,969 \\
\hline
\end{tabular}

Berdasarkan Tabel 3 hasil uji autokorelasi model regresi berganda di atas diketahui bahwa model yang diteliti mempunyai jumlah observasi sebesar 75, dengan jumlah variabel bebas sebesar 4. Nilai batas bawah (dl) yang diperoleh berdasarkan jumlah observasi dan jumlah variabel bebas adalah sebesar 1,515, dengan batas atas (du) sebesar 1,739. Hasil uji durbin watson statistik yang diperoleh dari pengujian adalah sebesar 1,969, nilai durbin watson tersebut berada di area $d_{U}<\mathrm{dw}<4-d_{U}$, atau berada diarea tidak ada autokorelasi. Dapat disimpulkan bahwa tidak ada autokorelasi pada model regresi yang digunakan.

\section{Uji Heteroskedastisitas}

Tabel 4. Hasil Uji Heteroskedastisitas

\begin{tabular}{|cl|r|r|}
\hline \multicolumn{1}{|c|}{} & \multicolumn{1}{c|}{$\mathrm{t}$} & Sig. \\
\hline 1 & (Constant) & $-1,003$ & 0,319 \\
& Dividend.Yield & $-0,177$ & 0,860 \\
& Retention.Ratio & 0,782 & 0,437 \\
& EPS & $-1,485$ & 0,142 \\
& ROE & 0,092 & 0,927 \\
\hline
\end{tabular}

Berdasarkan Tabel 4 di atas, diketahui nilai probabilitas dari seluruh variabel bebas lebih besar dari 0,05 , maka $\mathrm{H}_{0}$ diterima, sehingga dapat disimpulkan tidak ada heteroskedastisitas pada model regresi yang digunakan.

\section{Hasil Analisis Regresi}

Uji statistik F atau ANOVA pada dasarnya untuk menguji apakah semua variabel independen atau bebas yang dimasukkan dalam model dapat berpengaruh secara bersama-sama atau tidak terhadap variabel dependen. Berdasarkan output SPSS secara simultan pengaruh dari variabel 
independen, yaitu Dividend Yield, Retention Ratio, EPS, dan ROE terhadap Harga Saham adalah sebagai berikut:

Tabel 5. Hasil Uji F

\begin{tabular}{|rl|r|r|r|c|c|}
\hline \multicolumn{10}{|c|}{ ANOVA $^{\mathrm{b}}$} \\
Model & & Sum of & & & & \\
\hline 1 & Squares & df & Mean Square & F & Sig. \\
& Regression & 138,147 & 4 & 34,537 & 166,969 & $0,000^{\mathrm{a}}$ \\
& Residual & 14,479 & 70 & 0,207 & & \\
& Total & 152,626 & 74 & & & \\
\hline
\end{tabular}

Berdasarkan hasil uji $\mathrm{F}$ Tabel 5 di atas diketahui bahwa F-hitung sebesar 166,969 dengan nilai signifikansi sebesar $0,000<\alpha_{0,05}$, maka $\mathrm{H}_{0}$ ditolak yang berarti secara bersama-sama terdapat pengaruh antara Dividend Yield, Retention Ratio, EPS dan ROE terhadap Harga Saham.

\section{Uji Statistik t (Pengujian Hipotesis)}

Analisis data diperoleh dari hasil pengujian terhadap hipotesis. Pengujian hipotesa digunakan untuk melihat apakah terdapat pengaruh antara Dividend Yield, Retention Ratio, EPS dan ROE terhadap Harga Saham. Untuk menguji hipotesa dilakukan dengan uji statistik $\mathrm{t}$ yaitu apakah satu variabel independen secara individual dapat berpengaruh atau tidak terhadap variabel dependen dengan mengasumsikan variabel lain adalah konstan.

Berdasarkan output secara parsial pengaruh dari keempat variabel independen yaitu Dividend Yield, Retention Ratio, EPS dan ROE terhadap Harga Saham hasil perhitungan Uji t dapat dilihat pada Tabel 6 berikut ini:

Tabel 6. Hasil Uji Statistik t

Coefficients $^{\mathrm{a}}$

\begin{tabular}{|cl|r|r|r|r|c|}
\hline \multirow{2}{*}{ Model } & & \multicolumn{2}{|c|}{$\begin{array}{c}\text { Unstandardized } \\
\text { Coefficients }\end{array}$} & $\begin{array}{c}\text { Standardized } \\
\text { Coefficients }\end{array}$ & & \\
\cline { 3 - 5 } & & B & $\begin{array}{c}\text { Std. } \\
\text { Error }\end{array}$ & Beta & \multirow{2}{*}{ t } & Sig. \\
\hline \multirow{2}{*}{1} & (Constant) & 2,239 & 0,190 & & 11,782 & 0,000 \\
& Dividend.Yield & $-4,570$ & 1,671 & $-0,108$ & $-2,734$ & 0,008 \\
& Retention.Ratio & $-0,001$ & 0,002 & $-0,027$ & $-0,526$ & 0,601 \\
& EPS & 1,123 & 0,068 & 1,044 & 16,481 & 0,000 \\
& ROE & $-0,021$ & 0,015 & $-0,086$ & $-1,394$ & 0,168 \\
\hline
\end{tabular}

a. Dependent Variable: Harga.Saham berikut:

Adapun persamaan yang terbentuk dari pengujian regresi di atas adalah sebagai Harga Saham = 2,239 - 4,570 Dividend Yield -0,001 Retention Ratio + 1,123 EPS - 0,021 $R O E$. Berdasarkan hasil analisis dapat diketahui bahwa variabel bebas yang paling berpengaruh adalah variabel Earning per Share, kemudian disusul dengan variabel Dividend Yield, sedangkan variabel Return on Equity dan Retention Ratio tidak berpengaruh signifikan. 


\section{Uji Koefisien Determinasi}

Koefisien determinasi $\left(\mathrm{R}^{2}\right)$ pada intinya mengukur seberapa jauh kemampuan model dalam menerangkan variasi variabel dependen. Nilai koefisien determinasi adalah antara nol dan satu. Nilai $\mathbf{R}^{2}$ yang kecil berarti kemampuan variabel-variabel independen secara keseluruhan dalam menjelaskan variabel-variabel dependen sangat terbatas. Nilai yang mendekati satu berarti seluruh variabel-variabel independen memberikan hampir semua informasi yang dibutuhkan untuk memprediksi variasi variabel dependen.

Tabel 7. Hasil Uji Koefisien Determinasi

\begin{tabular}{|l|c|r|r|r|}
\hline Model & $\mathrm{R}$ & R Square & $\begin{array}{r}\text { Adjusted } \\
\text { R Square }\end{array}$ & $\begin{array}{r}\text { Std. Error of } \\
\text { the Estimate }\end{array}$ \\
\hline 1 & $0,951^{\mathrm{a}}$ & 0,905 & 0,900 & 0,45480 \\
\hline
\end{tabular}

Berdasarkan Tabel 7 hasil pengujian regresi berganda didapat nilai adjusted $R^{2}$ adalah 0,900. Artinya seluruh variabel independen yang terdiri dari Dividend Yield, Retention Ratio, EPS dan ROE mampu menjelaskan variasi dari variabel dependen yaitu Harga Saham sebesar $90 \%$, sedangkan sisanya yaitu sebesar $10 \%$ dapat dijelaskan oleh faktor-faktor lain yang tidak diikutsertakan dalam model penelitian.

\section{PEMBAHASAN}

Berdasarkan hasil statistik yang telah dijabarkan sebelumnya, maka pembahasan mengenai Dividend Yield, Retention Ratio, EPS, dan ROE terhadap Harga Saham adalah sebagai berikut:

\section{Pengujian Hipotesa 1}

Pengujian hipotesis 1 digunakan untuk menguji apakah dividend yield berpengaruh positif terhadap Harga saham. Dari Tabel 6 diketahui bahwa dividend yield bernilai -4,570 dengan probabilitas 0,008. Angka ini menyatakan bahwa dividend yield memiliki pengaruh negatif terhadap Harga Saham. Nilai probabilitas yang kurang dari 0,05 mempunyai arti bahwa dividend yield memiliki pengaruh signifikan terhadap Harga Saham akan tetapi negatif. Hipotesis dividend yield berpengaruh positif terhadap Harga saham tidak dapat didukung.

\section{Pengujian Hipotesa 2}

Pengujian hipotesis 2 digunakan untuk menguji apakah Retention Ratio berpengaruh negatif terhadap Harga saham. Dari Tabel 6 diketahui bahwa Retention Ratio bernilai -0,001 dengan probabilitas 0,601. Angka ini menyatakan bahwa Retention Ratio memiliki pengaruh negatif terhadap Harga Saham. Nilai probabilitas yang lebih dari 0,05 mempunyai arti bahwa Retention Ratio tidak memiliki pengaruh signifikan terhadap Harga Saham walaupun negatif. Hipotesis Retention Ratio berpengaruh negatif terhadap Harga saham tidak dapat didukung.

\section{Pengujian Hipotesa 3}

Pengujian hipotesis 3 digunakan untuk menguji apakah EPS berpengaruh positif terhadap Harga saham. Dari Tabel 6 diketahui bahwa EPS bernilai 1,123 dengan probabilitas 0,000. Angka ini menyatakan bahwa EPS memiliki pengaruh positif terhadap Harga Saham. Nilai probabilitas yang kurang dari 0,05 mempunyai arti bahwa EPS memiliki pengaruh signifikan terhadap Harga Saham dan bernilai positif. Hipotesis EPS berpengaruh positif terhadap Harga saham dapat didukung.

\section{Pengujian Hipotesis 4}

Pengujian hipotesis 4 digunakan untuk menguji apakah ROE berpengaruh positif terhadap Harga saham. Dari Tabel 6 diketahui bahwa ROE bernilai -0,021 dengan probabilitas 0,168. Angka ini menyatakan bahwa ROE memiliki pengaruh negatif terhadap Harga Saham. Nilai probabilitas yang lebih dari 0,05 mempunyai arti bahwa ROE tidak memiliki pengaruh signifikan terhadap Harga Saham dan bernilai negatif. Hipotesis ROE berpengaruh positif terhadap Harga saham tidak dapat didukung. 


\section{KESIMPULAN DAN SARAN \\ Kesimpulan}

Berdasarkan analisis yang telah dilakukan, maka menyimpulkan bahwa dari hasil uji t pada 25 perusahaan Perbankan Dividend Yield, Retention Ratio dan ROE terbukti tidak berpengaruh positif terhadap harga saham sehingga hipotesis ditolak. EPS berpengaruh positif sehingga hipotesis ketiga dapat diterima. Analisis data diperoleh dari hasil pengujian terhadap hipotesis. Pengujian hipotesa digunakan untuk melihat apakah terdapat pengaruh antara Dividend Yield, Retention Ratio, EPS dan ROE terhadap Harga Saham. Untuk menguji hipotesa dilakukan dengan uji statistik $t$ yaitu apakah satu variabel independen secara individual dapat berpengaruh atau tidak terhadap variabel dependen dengan mengasumsikan variabel lain adalah konstan

\section{Saran}

Penelitian ini memiliki beberapa saran baik saran secara praktis maupun empiris. Pertama, enelitian di masa mendatang dapat menggunakan sektor perusahaan yang berbeda dari sektor perusahaan di dalam penelitian ini, seperti perusahaan sektor manufaktur atau perusahaan sektor property, sehingga akan di dapat hasil penelitian yang lebih luas. Kedua, Diharapkan penelitian yang akan datang dapat mengeksplorasi variabel lain yang dapat berpengaruh terhadap harga saham. Ketiga, Penelitian mendatang dapat menambah periode tahun sehingga dapat menghasilkan penelitian yang lebih akurat.

\section{DAFTAR PUSTAKA}

Ariestiani, Fifi. 2014. Analisis Pengaruh ROE, Sales Growth, Dividend Yield, Firm Size, Book to Market, Momentum terhadap Volatilitas Return Saham. Jurnal Ekonomi Bisnis. Vol. 4. No. 2

Awat, Napa J. 1998. Manajemen Kebijakan Hutang, dan Kebijakan Dividen dalam Perspektif Keagenan. Simposium Nasional Akuntansi.

Brigham, Eugene F dan J.F Houston. 2001. Manajemen Keuangan. Buku Satu Edisi Kesepuluh. Jakarta: Salemba Empat Jogiyanto, Hartono. 2000. Teori Portofolio dan Analisis Investasi. Yogyakarta: BPFE.

Baskin, J., 1989, “An Empirical Investigation of the Pecking Order Hypothesis,” Financial. Management Spring, 26-35Allen dan Rachim (1996).

Bhattacharya, Sudipto, 1979, Imperfect information, dividend policy, and 'The bird in the hand' fallacy, Bell Journal of Economics.

Darmadji, Tjiptono dan Hendy M.Fakhrudin. 2006, Pasar Modal di Indonesia Pendekatan Tanya Jawab. Jakarta: Salemba Empat.

Deitiana, Tita (2011), Pengaruh Rasio Keuangan, Pertumbuhan Penjualan, dan Dividen Terhadap Harga Saham. Jurnal Bisnis dan Akuntansi. Vol. 13, No.1. Hlm. 57-66.

Darsono dan Ashari, 2005, Pedoman Praktis Memahami Laporan Keuangan, Edisi kesatu, Andi, Yogyakarta 
Eduardus, Tandelilin. 2007, Analisis Investasi dan Manajemen Portofolio. Yogyakarta: BPFE

Fadhlilla, Rifqi Riadhi \& Muhammad Rafqi Nazar. 2015, Pengaruh Kebijakan Dividen, Earning Per Share (EPS), Return On Equity (ROE), Profit After Tax (PAT) terhadap Harga Saham Perusahaan Sektor Properti dan Real Estate yang terdaftar pada Bursa Efek Indonesia Periode 2011-2013. Jurnal Ekonomi dan Bisnis. Universitas Telkom.

Fakhruddin. 2008. Istilah Pasar Modal A-Z. Jakarta: Elex Media Komputindo. Ikatan Akuntan Indonesia. (2007)

Ghozali, Imam. 2007, Aplikasi Analisis Multivariate dengan Program SPSS. Semarang: Badan Penerbit Universitas Diponegoro.

Horne, James C. Van dan John M. Wachowics. 2007. Prinsip-prinsip Manajemen Keuangan (Buku 1). Jakarta: Salemba Empat.

Hunjra, Ahmed Imran, Muhammad Shahzad, Muhammad Irfan Chani, Sabihul Hasan, Umer Mustafa. 2014. Impact of Dividend Policy, Earning Per Share, Return on Equity, Profit After Tax on Stock Prices. International Journal of Economics and Empirical Research. 2(3), 109-115.

Hendriksen, E. S., dan M. Breda. 2000, Teori Akunting (Terjemahan). Edisi Kelima. Buku Kesatu. Batam Centre: Interaksara.

Ichsan, Rhandhy. Dan Salma Taqwa. 2013. Pengaruh Informasi Laba, Kebijakan Dividen an Profitabilitas terhadap Harga Saham pada Perusahaan Terdaftar di Bursa Efek Indonesia. WRA, Vol. 1, No. 2, Oktober 2013.

Iqbal, Arslan, Farooq Ahmed, dan Ali Raza Shafi. 2014, "The Effect of Dividend Bubble on Share Price: Evidence from KSE-30 Index". Research Journal of Finance and Accounting, ISSN 2222-1697 (Paper) ISSN 2222-2847 (Online).

Istanti (2010), Pengaruh Kebijakan Dividen Terhadap Harga Saham Pada Perusahaan LQ 45. Jurnal Ekonomi Bisnis.

Kajian Stabilitas Keuangan (KSK), No. 23 September 2015. Bank Indonesia: Jakarta

Khan, Kanwal Iqbal. 2012, Effect of Dividends on Stock Prices - A Case of Chemical and Pharmaceutical Industry of Pakistan. Management 2012, 2(5): 141-148.

Masum, Abdullah Al. 2014, Dividend Policy and Its Impact on Stock Price - A Study on Commercial Banks Listed in Dhaka Stock Exchange. Global Disclosure of Economics and Business, Volume 3, No 1 (2014).

Miller, M. dan K. Rock. 1985. “Dividend Policy under Asymmetric Information”.

Majanga, B. Byson (2015) ,The Dividend Effect on Stock Price-An Empirical Analysis of Malawi Listed Companies. Accounting and Finance Research, Vol. 4, No. 3; 2015. 
Margaretha, Farah dan Damayanti, Irma. 2008. Pengaruh Price Earning Ratio, Dividend Yield dan Market to Book Ratio terhadap Stock Return di Bursa Efek Indonesia. Jurnal Bisnis dan Akuntansi. Vol. 10. No. 2. Mei : 2671 -2684. ISSN: 1693-8305.

Meythi, Tan Kwang En, dan Linda Rusli. 2011. "Pengaruh Likuiditas dan Profitabilitas terhadap Harga Saham Perusahaan Manufaktur yang Terdaftar di Bursa Efek Indonesia”. Jurnal Bisnis Manajemen dan Ekonomi. Vol. 10. No. 2. Mei : 2671 -2684. ISSN: $1693-8305$.

Sia, Vice Law Ren \& Lauw Tjun Tjun. 2011, Pengaruh Current Ratio, Earnings per Share, dan Price Earnings Ratio Terhadap Harga Saham, Jurnal Akuntansi Vol.3 No.2 November 2011: 136 - 158 .

Sugiyono. 2009. Metode Penelitian Bisnis. Bandung : CV Alfabeta.

Setiyawan, Indra dan Pardiman. 2014. "Pengaruh Current Ratio, Inventory Turnover, Time Interest Earned dan Return On Equity terhadap Harga Saham pada Perusahaan Manufaktur Sektor Barang Konsumsi yang Terdaftar di BEI Periode 2009-2012”. Jurnal Nominal. Vol. III. No. 2.

Sunariyah. 2004, Pengantar Pengetahuan Pasar Modal. Cetakan Keempat.

Sundjaja Ridwan S. dan Inge Barlian. 2003. Manajemen Keuangan 1, Edisi kelima.

Sekaran, Uma. 2003. Metodologi Penelitian Bisnis. Jakarta: Salemba Empat.

Pranowo, Bambang. 2009. Pengaruh Beberapa Kinerja Keuangan terhadap Harga Saham Perusahaan. Jurnal Ekonomi Bisnis. Thn 14. No. 3. November 2009.

Robbert Ang (1997), Ang, Robert. 1997. Buku Pintar: Pasar Modal Indonesia. Jakarta: Mediasoft.

Venusita, Lintang. 2013. Reposisi Fungsi Lembaga Bank dan Non Bank dalam Upaya Pemberdayaan Ekonomi Kerakyatan, Penerapan Good Governance dan Pengembangan Otonomi Daerah. Jurnal Akuntansi Aktual, Vol. 2, Nomor 2, Juni 2013, hlm. 67-75.

Wijayanti, Puput. 2013, Pengaruh Intellectual Capital Terhadap Harga Saham Melalui Kinerja Keuangan. Jurnal Ekonomi Bisnis. Vol: 2 No: 1 Tahun 2013.

Yesi, Yudi Ari. 2015. Pengaruh Earning Volatility, Dividend Yield, Growth in Asset dan Size terhadap Volatilitas Harga Saham pada Perusahaan Manufaktur Tahun 2011-2013. Jurnal Ekonomi dan Bisnis. Universitas Muhammadiyah Surakarta.

Zarezadeh, Elham. Seyed Heidar dan Hassan Deghghan Dehavi. 2011. Fitting the Relationship between Financial Variables and Stock Price through Fazzy Regression Case Study: Iran Khondro Company”. International Journal of Business and Social Science. Vol. 2. No. 11.

Undang-Undang Pasar Modal No.8 tahun 1995 